\title{
PELATIHAN PENGEMBANGAN KELAS DIGITAL BERBASIS MICROSOFT 365 DI SEKOLAH MUHAMMADIYAH DKI JAKARTA
}

\author{
Gufron Amirullah $^{1}$, Maesaroh $^{2}$ \\ ${ }^{1,2)}$ Program Studi Pendidikan Biologi, Fakultas Keguruan dan Ilmu Pendidikan, Universitas Muhammadiyah \\ Prof. Dr. Hamka \\ e-mail: maesyaroh@uhamka.ac.id
}

\begin{abstract}
Abstrak
Peristiwa pandemi global berdampak pada proses pembelajaran di sekolah. Pembelajaran harus dilakukan secara daring memanfaatkan teknologi guna mencegah interaksi fisik pada satu tempat yang sama. Proses pembelajaran secara daring diprediksikan akan tetap dilaksanakan di masa mendatang dan pada masa new normal saat ini. Proses pembelajaran selalu memiliki tiga tujuan yang akan dicapai yaitu perubahan peserta didik pada ranah afektif, kognitif, dan psikomotorik. Proses pembelajaran yang dilakukan secara daring seharusnya tetap dapat mencapai tujuan pembelajaran. Perkembangan teknologi informasi dan komunikasi atau Information and Communication of Technology (ICT) tidak dipungkiri telah memasuki berbagai lini kehidupan, salah satunya dalam bidang pendidikan. Pada proses kegiatan belajar mengajar di kelas, salah satu produk dalam bidang ICT yaitu Microsoft 365 berupa one note, sway, dan teams, forms dapat digunakan untuk mencapai tujuan pembelajaran secara daring. Microsoft office 365 memudahkan pendidik untuk berbagi dan berkolaborasi dalam hal dokumen pembelajaran yang dapat mendukung proses maupun evaluasi pembelajaran daring yang memanfaatkan koneksi internet. Pengembangan kelas digital berbasis Microsoft 365 telah dilatihkan kepada sebanyak 19 orang guru di sekolah Muhammadiyah DKI Jakarta dengan hasil evaluasi berupa 89,4\% peserta menyatakan pelatihan sesuai dengan kebutuhan guru. Melalui pelatihan pembelajaran digital berbasis Microsoft 365 diharapkan dapat berkontribusi dalam peningkatan kualitas proses pembelajaran secara daring.
\end{abstract}

Kata kunci: Pembelajaran Daring, Guru Biologi, Microsoft 365, sekolah Muhammadiyah

\begin{abstract}
The global pandemic gives the impact on the learning process in schools. Learning process should be online using technology to prevent physical interaction in the same place. It is predicted that the online learning process will continue in the future and in the current new normal. The learning process always has three goals to be achieved, namely changes in students in the affective, cognitive, and psychomotor domains. The online learning process should still be able to achieve learning goals. The development of information and communication technology or Information and Communication of Technology (ICT) has entered in various lines of life, one of it is in the field of education. In the process of teaching and learning activities, one of the products in the ICT field namely Microsoft 365 is in the form of one note, sway, and teams, forms can be used to achieve online learning goals. Microsoft office 365 makes easy for educators to share and collaborate on learning documents that can support online learning processes and evaluations that utilize an internet connection. The development of digital class based on Microsoft 365 has been trained for 19 teachers at the Muhammadiyah schools of DKI Jakarta with the results of the evaluation in the form of $89.4 \%$ of participants who stated that the training was in accordance with the needs of the teacher. Through Microsoft 365-based digital learning training, it is hoped that it can contribute to improving the quality of the online learning process.
\end{abstract}

Keywords: Online Learning, Biology Teachers, Microsoft 365, Muhammadiyah Schools 


\section{PENDAHULUAN}

Terjadinya peristiwa pandemi global yang disebabkan oleh penyebaran virus Covid-19 di seluruh dunia sejak akhir tahun 2019 berdampak besar pada proses pendidikan. Proses pembelajarn yang lazimnya dilakukan di kelas, terjadi tatap muka langsung antara pendidik dan peserta didik terpaksa harus dilakukan secara daring memanfaatkan teknologi guna mencegah interaksi pada satu tempat yang sama. Hal tersebut dilakukan hampir di seluruh lembaga pendidikan di dunia dengan tujuan mencegah penyebaran virus. Melalui kebijakan tersebut ternyata menjadikan para guru menjadi lebih kreatif dan inovatif dalam mencari serta menggunakan media penyampaian materi atau bahan ajar di kelas sesuai dengan kemampuan guru dan peserta didik (Lestari \& Gunawan, 2020).

Pada seluruh proses pembelajaran selalu memiliki tiga tujuan yang akan dicapai yaitu perubahan peserta didik pada ranah afektif, kognitif, dan psikomotorik. Proses pembelajaran yang dilakukan secara daring seharusnya tetap dapat mencapai tujuan pembelajaran. Perkembangan teknologi informasi dan komunikasi telah memasuki bidang pendidikan. Teknologi dapat digunakan hampir pada semua sektor manajemnen pendidikan. Pada proses kegiatan belajar mengajar di kelas, salah satu produk dalam bidang teknologi berupa Microsoft 365 yang dapat dimanfaatkan untuk mencapai tujuan pembelajaran secara online. Microsoft office 365 dapat memudahkan pendidik untuk berbagi dan berkolaborasi dalam hal dokumen pembeljaran, serta mendukung proses maupun evaluasi pembelajaran daring yang memanfaatkan koneksi internet.

Microsoft office 365 merupakan aplikasi office cloud dari Microsoft yang memungkinkan penggunanya untuk mengakses dan berbagi konten secara daring dengan bantuan internet. Pengembangan kelas digital berbasis Microsoft 365 telah dilatihkan kepada 19 guru-guru sekolah Muhammadiyah di DKI Jakarta. Kegiatan pelatihan ini memiliki tujuan untuk 1) memberikan pengetahuan tentang makna dan dampak pemanfaatan kelas digital dalam bidang pendidikan, 2) memberikan pengetahuan penggunaan model pembelajaran digital berbasis Microsoft 365 dalam proses belajar, 3) memberi pelatihan tentang pemanfaatan Microsoft 365 pada kelas digital materi biologi.

Melalui Microsoft forms guru dapat membuat sebuah evaluasi berupa kuis maupun kuesioner. Microsoft sway dapat digunakan oleh guru untuk membuat presentasi dan laporan interaktif. Microsoft power point 365 juga dapat digunakan untuk membuat animasi 3D. Sedangkan melalui pembelajaran dengan Microsoft one note dengan teknik mind mapping peserta didik dapat meningkatkan hasil belajar pada bidang biologi materi system pencernaan (Alvia, Nurhayati, \& Rachmawaty, 2018). One note dapat melibatkan peserta didik berpartisipasi dalam proses pembelajaran karena ada fitur personalize yang dapat menjangkau setiap kebutuhan siswa secara individu. Selain itu, fitur minimize dari one note memiliki keunggulan dapat mengurangi penggunaan kertas. Peserta didik dapat mengakses one note dengan waktu yang sangat fleksible melalui personal computer atau smartphone yang terhubung ke jaringan internet. Sedangkan fitur strategize mampu meningkatkan motivasi dan minat belajar peserta didik dalam mencapai tujuan pembelajaran. (Wahyuningsih \& Waluya, 2017), (Usodo, et all, 2016). (Aribowo \& Setianingtyas, 2018), (Wijaya, 2019). Oleh karena itu, berbagai fitur Microsoft Office 365 dilatihkan kepada guru berupa one note, sway teams dan forms diharapkan dapat meningkatkan kualitas proses pembelajaran daring.

\section{METODE}

Proses pendidikan dan pelatihan kepada guru merupakan salah satu jalan untuk mengatasi masalah kesiapan guru dalam melaksanakan instruksi pembelajaran secara online. Melalui proses pendidikan dan pelatihan tentang pembelajaran digital berbasis Microsoft 365 diharapkan 
berdampak pada lancarnya komunikasi pembelajaran di kelas pada masa pandemic menuju era new normal sehingga meningkatnya daya serap peserta didik terhadap materi yang diberikan guru.

Mitra pada kegiatan ini adalah guru-guru di sekolah Muhammadiyah wilayah DKI Jakarta. Kegiatan pelatihan ini dilaksanakan sebanyak empat kali pertemuan pada bulan Juli tahun 2020 dengan metode blended learning, yang terdiri dari tiga kali pertemuan daring dan satu kali pertemuan secara tatap muka. Platform yang digunakan dalam kegiatan ini yaitu Microsoft 365, WhatsApp group dan Zoom meetings. Kegiatan ini bertujuan memberi pengetahuan dan keterampilan mengajar dengan Microsoft 365.

\section{HASIL DAN PEMBAHASAN}

Hasil kegiatan kemitraan masyarakat dalam bentuk pelatihan pengembangan kelas digital berbasis Microsoft 365 disajikan dalam Tabel berikut:

Tabel 1. Hasil evaluasi kegiatan pelatihan pengembangan kelas digital berbasis Microsoft 365

\begin{tabular}{|c|l|c|c|c|c|}
\hline No. & \multicolumn{1}{|c|}{ Pernyataan } & SS & S & TS & STS \\
\hline 1. & Pelatihan sesuai dengan kebutuhan saya & $36,8 \%$ & $52,6 \%$ & $5,3 \%$ & $5,3 \%$ \\
\hline 2. & $\begin{array}{l}\text { Fasilitator mampu mengadakan pendekatan } \\
\text { yang baik dengan peserta }\end{array}$ & $31,6 \%$ & $63,1 \%$ & - & $5,3 \%$ \\
\hline 3. & $\begin{array}{l}\text { Ilustrasi dan contoh-contoh yang diberikan } \\
\text { sesuai kondisi kerja peserta }\end{array}$ & $26,3 \%$ & $68,4 \%$ & - & $5,3 \%$ \\
\hline 4. & $\begin{array}{l}\text { Bahasa yang digunakan fasilitator mudah } \\
\text { dimengerti }\end{array}$ & $21,1 \%$ & $78,9 \%$ & - & - \\
\hline 5. & $\begin{array}{l}\text { Fasilitator mampu membawakan materi dengan } \\
\text { menarik }\end{array}$ & $31,6 \%$ & $68,4 \%$ & - & - \\
\hline 6. & $\begin{array}{l}\text { Fasilitator bersemangat (antusias) dalam } \\
\text { menyampaikan materi pelatihan }\end{array}$ & $36,8 \%$ & $57,9 \%$ & - & $5,3 \%$ \\
\hline
\end{tabular}

Berdasarkan Tabel 1 diketahui bahwa lebih dari separuh populasi peserta penelitian yaitu 89,4 $\%$ menyatakan bahwa kegiatan pelatihan ini sesuai dengan kebutuhan para guru. Sedangkan peserta yang menyatakan pelatihan ini tidak sesuai dengan kebutuhan mereka sebanyak 10,6\% . Hasil penelitian ini sejalan dengan (Pradja \& Baist, 2019) yang menyatakan bahwa Microsoft teams yang merupakan salah satu bagian aplikasi dari Microsoft 365 memiliki manfaat yang besar dalam pelaksanaan pembelajaran secara online. Melalui Microsoft teams guru dan peserta didik dapat berkolaborasi informasi dan data dari proses pembelajaran online. Fasilitas percakapan yang terdapat dalam aplikasi ini juda dapat mereduksi gap atau kesenjangan di kelas melakui kegiatan diskusi. Selain itu, terdapat fitur menggunggah data, audio, video, serta tautan yang dapat diunduh oleh anggota dalam group Microsoft teams. Selain dibutuhkan oleh guru, keterampilan mengoperasikan Microsoft 365 juga mutlak diperlukan oleh peserta didik untuk kebutuhan kelancaran pembelajaran online (Handayani \& Hadi, 2020).

Pada penilaian tentang fasilitator kegiatan, sebanyak $94,7 \%$ peserta pelatihan setuju bahwa fasilitator kegiatan mampu melakukan pendekatan dengan peserta kegiatan. Terdapat 5,3\% peserta pelatihan yang menyatakan fasilitator tidak dapat melakukan pendekatan dengan baik. Sebanyak 94,7 \% peserta pelatihan menyatakan bahwa fasilitator memberikan ilustrasi dan contoh dalam kegiatan pelatihan sesuai dengan kondisi kerja peserta pelatihan, sedangkan sedangkan 5,3\% peserta pelatihan menyatakan hal yang berbeda yaitu contoh dan ilustrasi yang diberikan tidak sesuai dengan kondisi kerja peserta pelatihan. Fasilitator kegiatan pelatihan pengembangan kelas digital berbasis Microsoft 365 dinyatakan sudah menggunakan Bahasa yang mudah dipahami oleh peserta kegiatan dengan persentase sebanyak $100 \%$.

Pada bagian yang lain, seluruh populasi peserta pelatihan menyatakan bahwa fasilitator dapat membawakan materi dengan menarik, dengan persentase sebanyak $68,4 \%$ yang memberi pernyataan "setuju" dan sebanyak $31,6 \%$ peserta menyatakan sangat setuju. Pada penilaian terakhir, peserta pelatihan menyatakan bahwa fasilitator bersemangat dalam menyampaikan materi pelatihan dengan persentase sebanyak $94,7 \%$, sedangkan $5,3 \%$ sisanya menyatakan hal yang 
berbeda. Hasil penelitian (Harefa et all, 2019) menunjukkan bahwa pembelajaran proyek menggunakan sway pada Microsoft 365 memberikan dampak yang berbeda secara signifikan daripada pembelajaran proyek yang menggunakan handout konvensional. Microsoft 365 merupakan salah satu aplikasi pembelajaran gratis yang direkomendaikan unutk proses pembelajaran daring (Abidin, Rumansyah, \& Arizona, 2020).

Pembelajaran daring menggunakan internet yang komunikatif dan kolaboratif dapat dilakukan hanya dengan satu paket aplikasi atau platform secara gratis yaitu Microsoft Office 365 (Suprianto, 2018). Proses pembelajaran digital berbasis Microsoft 365 yang memanfaatkan internet dinilai memiliki banyak keuntungan bagi guru, peserta didik dan pihak sekolah diantaranya yaitu: 1) tidak membutuhkan server komputer atau laptop untuk menyimpan dokumen pembelajaran; 2) pengaksesan dokumen tidak terikat ruang dan waktu atau dapat diakses kapanpun dan di manapun; 3) memiliki ruang penyimpanan dokumen pembelajaran yang besar; 4) pengguna dapat berkolaborasi dan berbagi dokumen (Effendi, 2016)

\section{SIMPULAN}

Berdasarkan hasil penelitian dan pembahasan, maka dapat disimpulkan: 1) Terdapat empat fitur dalam Microsoft 365 yang dilatihkan kepada para guru yaitu: Microsoft sway, one note, teams dan forms; 2) Pelatihan pengembangan kelas digital berbasis Microsoft 365 dinilai sesuai dengan kebutuhan para guru; 3) Pelaksanaan pelatihan pengembangan kelas digital berbasis Microsoft 365 dinilai baik oleh peserta kegiatan.

\section{SARAN}

Berdasarkan simpulan penelitian, maka beberapa hal yang dapat disarankan yaitu: 1) pelaksanaan pelatihan agar dilanjutkan pada platform pembelajaran yang lain, dengan harapan terjadinya variasi metode dan media pembelajaran yang dilakukan oleh guru kepada peserta didik; 2) pelatihan dapat diberikan kepada pada guru dengan ruang lingkup dan jenjang pendidikan yang lebih luas.

\section{UCAPAN TERIMA KASIH}

Penulis berterima kasih kepada Lembaga Pengabdian dan Pemberdayaan Masyarakat (LPPM) Universitas Muhammadiyah Prof. Dr. Hamka (UHAMKA) yang telah mendanai kegiatan Pogram Kemitraan Masyarakat ini.

\section{DAFTAR PUSTAKA}

Abidin, Z., Rumansyah, Arizona, K. (2020). Pembelajaran Online Berbasis Proyek Salah Satu Solusi Kegiatan Belajar Mengajar di Tengah Pandemi Covid-19. Jurnal Ilmiah Profesi Pendidikan. 5 (1). 64-70.

Alvia, N., Nurhayati, B., Rachmawaty. (2018). Pengaruh Penerapan Media Mind Mapping Terintegrasi Dengan Aplikasi Microsoft Onenote Terhadap Hasil Belajar Peserta Didik Pada Materi Pelajaran Sistem Pencernaan Di Kelas XI SMAN 12 Makassar. Prosiding Seminar Nasional Biologi dan Pembelajarannya. Hal. 365-370.

Aribowo, E., K., \& Setianingtyas, A., F. (2018). Pelatihan Pemanfaatan Microsoft ${ }^{\circledR}$ office 365 bagi Pendidik di Kabupaten Klaten untuk Mewujudkan 21st Century Learning: Sebuah Langkah Awal. Seminar Nasional Pengabdian kepada Masyarakat "Hilirisasi Hasil Penelitian melalui Program Pengabdian Berkelanjutan". 1-8.

Effendi, M. R. (2016). Penerapan Teknologi Cloud Computing di Universitas (Studi kasus: fakultas teknologi informasi Universitas Bayangkara Jakarta). Jurnal Teknologi Informasi Program Studi Teknik Informatika dan Sistem Informasi, Universitas Bunda Mulia. 12 (1). 7 14

Handayani, S., Hadi, S. (2020). Pelatihan E-Learning Menggunakan Office 365 Bagi Guru-Guru dan Siswa-Siswa Madrasah Aliyah Negeri 1 Semarang. JPKMI (Jurnal Pengabdian Kepada 
Masyarakat Indonesia). 1 (2). 49-58.

Harefa, N., Silalahi, N.F.D., Sormin, E., Purba, L.S.L., Sumiyati. (2019). The difference of students' learning outcomes with project based learning using handout and sway Microsoft 365. Jurnal Pendidikan Kimia 11(2). 24-30.

Lestari, P. A.S., Gunawan. (2020). The Impact of Covid-19 Pandemic on Learning Implementation of Primary and Secondary School Levels. Indonesian Journal of Elementary and Childhood Education. 1(2). 58 - 63.

Pradja, B. P., \& Baist, A. (2019). Analisis Kualitatif Penggunaan Microsoft Teams dalam Pembelajaran Kolaboratif Daring. Seminar Nasional Matematika Dan Pendidikan Matematika (4th Senatik), 415-420.

Suprianto. (2018). Perancangan E-Learning Menggunakan Office 365 dalam Proses Belajar Mengajar. Seminar Nasional Royal (SENAR). 381-386.

Usodo, B., Sutopo, Ekana, C., H., Kurniawati, I., Kuswardi, Y. (2016). Pelatihan Penerapan Beberapa Aplikasi dari Microsoft: office mix, onenote, sway dalam Pembelajaran bagi Guruguru Matematika SMA di Kabupaten Sragen. Jurnal Elektronik Pembelajaran Matematika. 4 (9). 743-752.

Wahyuningsih, P., \& Waluya, S. B. (2017). Kemampuan Literasi Matematika Berdasarkan Metakognisi Siswa pada Pembelajaran CMP Berbantuan Onenote Class Notebook. Unnes Journal of Mathematics Education Research. 6(1), 18-29.

Wijaya, Tony. (2019). Pembuatan Modul Pembelajaran dengan PowerPoint Animasi 3D. Seminar Nasional Hasil Pengabdian Kepada Masyarakat. 164-168. 